\title{
Volatile Ester Suppression and Recovery following 1-Methylcyclopropene Application to Apple Fruit
}

\author{
Alejandra Ferenczi \\ Department of Horticulture, Michigan State University, East Lansing, MI 48824 \\ Jun Song \\ Agriculture and Agri-Food Canada (AAFC), Atlantic Food and Horticulture Research Centre, 32 Main \\ Street, Kentville, Nova Scotia B4N 1J5 Canada
}

Meisheng Tian

Horticultural and Food Research Institute of New Zealand Ltd., Mt Albert Research Center, Private Bag 92169 Auckland, New Zealand

Konstantinos Vlachonasios

Department of Biology, Aristotle University of Thessaloniki, Macedonia, Greece

David Dilley and Randolph Beaudry ${ }^{1}$

Department of Horticulture, Michigan State University, East Lansing, MI 48824

\begin{abstract}
Additional Index words. ethylene, aroma, 1-MCP, AAT, ACC oxidase, quality
ABstract. The effect of 1-methylcyclopropene (1-MCP) on biosynthesis of volatiles and fruit ripening in apple (Malus $x$ domestica Borkh.) was investigated using 'Golden Delicious', 'Jonagold', and 'Redchief Delicious' fruit. Application of 1-MCP to 'Golden Delicious' at the preclimacteric stage effectively inhibited ripening as determined by decreased expression of genes for 1-amino-1-cyclopropane carboxylic acid (ACC) oxidase (ACO), and ACC synthase, ACO protein content, climacteric ethylene production, respiration, and volatile ester biosynthesis. Exogenous ethylene applied after 1-MCP treatment did not induce ethylene production, respiration, or volatile production. Activity for alcohol acyltransferase, which catalyzes the final step in ester formation, was demonstrable for 1-MCP-treated fruit, indicating no strict limitation on ester formation is imposed by this enzyme and that ester formation in 1-MCP-treated apple fruit is at least partially limited by reduced substrate synthesis. Once volatile ester formation had been suppressed by 1 -MCP, the recovery of volatile synthesis required $\approx 3$ weeks for 'Jonagold' and 4 weeks for 'Delicious' when held in air at $22{ }^{\circ} \mathrm{C}$. For the first 2 months of storage at $0{ }^{\circ} \mathrm{C}$ in air, 'Jonagold' and 'Delicious' required $\approx 3$ weeks holding at $22{ }^{\circ} \mathrm{C}$ for volatile biosynthesis to initiate; after 5 months in refrigerated storage, volatile formation was evident at the time of removal from cold storage. For 'Jonagold' fruit held in controlled atmosphere (CA) storage for 2, 5, and 7 months at 0 ${ }^{\circ} \mathrm{C}$, at least 3 weeks holding at $22{ }^{\circ} \mathrm{C}$ were required for volatile formation to begin to recover. The maximal amount of volatile formation was reduced $50 \%$ by 1 -MCP relative to nontreated control fruit. CA storage had a similar impact on maximal volatile formation. The marketing of 1-MCP-treated fruit soon after treatment might result in the delivery of fruit to the consumer with little likelihood of recovery of volatile ester formation prior to consumption.
\end{abstract}

Apple aroma depends upon a complex mixture of organic compounds, some of which are produced upon the disruption of the tissue during mastication, but many of which are produced autonomously by the fruit during ripening (Fellman et al., 2000). Esters are quantitatively and qualitatively the most important autonomously produced volatile compounds contributing to apple aroma (Dixon and Hewett, 2000; Fellman et al., 2000). Ester production in apple fruit is an ethylene-dependent process and the majority of the esters are synthesized during the climacteric phase of ripening (Fan et al., 1998; Song and Bangerth, 1996).

Storage of apples in low oxygen atmospheres, which inhibits ethylene production and action, has been widely shown to sup-

Received for publication 28 Apr. 2006. Accepted for publication 23 June 2006. We thank AgroFresh for their financial support, Dr. E. Sisler for kindly supplying gaseous 1-MCP, and Drs. S.F. Yang and G. Hrazdina for kindly providing cDNA inserts for $M d A C O 1$ and $M d A C S 1$, respectively. We thank Dr. C. Forney for critical review and T.J. McCully for his technical assistance. Use of trade names does not imply endorsement of the products named or criticism of similar ones not named.

'To whom reprint requests should be addressed. E-mail address: beaudry@msu. edu. press autonomous aroma volatile production (Brackmann et al., 1993; Fellman et al., 2000; Gorny and Kader, 1996; Mattheis et al., 1995; Patterson et al., 1974) and can reduce perceived aroma intensity and quality (Boylston et al., 1994; Plotto et al., 1999; Williams and Langron, 1983). Similarly, the ethylene action inhibitor, 1-MCP suppresses the formation of aroma-related volatiles (Abdi et al., 1998; Fan et al., 1999; Fan and Mattheis, 1999; Golding et al., 1998; Lurie et al., 2002) and suppresses the expression of genes associated with the pathways of ester formation, including alcohol acyl-transferase (AAT) (Defilippi et al., 2005), which transfers an acyl group from a CoA thioester to an alcohol in the final step of ester biosynthesis. It is believed that this enzyme imparts some limitation on the formation of esters in apple fruit in which ethylene action has been inhibited by growth regulators such as 1-MCP or in which ethylene perception has been impaired (Defilippi et al., 2004, 2005).

Like CA storage, 1-MCP has the potential to impact the perception of fruit aroma quality. Lurie et al. (2002) found that $1-\mathrm{MCP}$ induced a moderate reduction in volatiles that qualitatively altered olfactory perception of diced 'Anna' fruit. Despite reduced production of total volatiles by the $1-\mathrm{MCP}$ treated apple 
pieces, a reduction in the "ripe" aroma character was associated with higher acceptability. Nevertheless, a more severe reduction in odor-active compounds by 1-MCP than that achieved in the cited study may negatively impact aroma quality.

The process of recovery of the biosynthesis of esters and other ripening-related volatiles from the effects of 1-MCP has not been evaluated extensively. Mattheis et al. (2005) found that following removal from storage, volatiles from 'Gala' fruit tended to increase with duration of storage in air with and without 1-MCP treatment, although the absolute level of volatiles was reduced by 1-MCP. Under conditions of CA storage with and without 1MCP, volatile production upon removal from storage declined as storage duration increased. Additional information regarding the ontogeny of ripening and volatile formation following 1-MCP treatment may help optimize storage regimes for the delivery of the highest quality fruit to the consumer. Our goal was to evaluate the timing of ripening events immediately following 1-MCP application and to detail the duration of 1-MCP suppression of the formation of esters and other volatiles for apple fruit stored in refrigerated air (RA) and CA storage and to more fully describe the extent and rapidity of the recovery of the capacity for volatile synthesis.

\section{Materials and Methods}

Two experiments were conducted. The objective of the first experiment was, using 'Golden Delicious' apple fruit, to evaluate the impact of 1-MCP on initial volatile suppression and the inhibition of two broadly accepted physiological measures of fruit ripening, ethylene formation and respiration. To further assess and verify the impact of 1-MCP on ripening, the effect of 1-MCP on gene expression for ACC synthase (ACS) and ACO as well as protein analysis of ACO were determined. To determine if volatile suppression by inhibition of ethylene action was by limiting AAT in the final reaction in the synthesis pathway of esters, immediate precursors to this step were applied exogenously. In the second experiment, we determined the time required for 'Jonagold' and 'Redchief Delicious' apple fruit to recover their capacity to produce esters and other volatiles (collectively termed "total volatiles") either immediately after treatment or following storage in RA or CA at $0{ }^{\circ} \mathrm{C}$. In both experiments, 1-MCP was applied to preclimacteric apples.

\section{Expt. 1}

Plant material. Sixty 'Golden Delicious' apple fruit were harvested in the orchard of the Horticultural Teaching and Research Center at Michigan State Univ. in early Oct. 1997. The internal ethylene concentration of 10 representative fruit was measured by analyzing a 1-mL gas sample withdrawn from the internal air space of the core of the fruit ovary as previously described (Mir et al., 2001) to determine if fruit ripening had initiated. At the time of harvest, the range of internal ethylene concentrations in the fruit was from 0.1 to $0.3 \mu \mathrm{L} \cdot \mathrm{L}^{-1}$. The remaining fruit were used for the following studies.

1-MCP TREATMent. To impose the 1-MCP treatment, 18 fruit were placed in a $9.5-\mathrm{L}$ glass desiccator and held at $22{ }^{\circ} \mathrm{C}$ and 1-MCP gas was added directly to the container atmosphere. 1MCP stock gas, contained in an amber glass bottle fitted with a crimp-top cap with Teflon septum (a gift from E.C. Sisler) was used as a source for 1-MCP. 1-MCP gas was removed from the stock gas using a glass syringe fitted with a Teflon-tipped plunger and injected into the jars to yield a final 1-MCP concentration of $0.5 \mu \mathrm{L} \cdot \mathrm{L}^{-1}$. The containers were sealed for $14 \mathrm{~h}$ then ventilated for $2 \mathrm{~h}$ to release the 1-MCP. Fifteen nontreated control fruits were enclosed in a similar container for the same period of time and also ventilated for $2 \mathrm{~h}$. $\mathrm{O}_{2}$ levels were not monitored while containers were sealed, but at typical respiratory rates measured, would be expected to deplete $\approx 600 \mathrm{~mL}$ of the $\approx 2000 \mathrm{~mL}$ of $\mathrm{O}_{2}$ resident in the system upon sealing, yielding a decline of $\approx 6 \mathrm{kPa}$ from the initial $21 \mathrm{kPa} \mathrm{O}_{2}$. After the treatment period, fruit were randomly placed into ventilated 1.9-L glass jars, three fruit per jar ( $\approx 500-650 \mathrm{~g})$, and held at $22^{\circ} \mathrm{C}$ for a total of six jars for the 1-MCP-treated fruit and five jars for the control fruit. Of these, three containers were used for monitoring respiration, ethylene production, and fruit volatile production for control and treated fruit for the first $11 \mathrm{~d}$ of the study. After $11 \mathrm{~d}$, the three containers having 1-MCP-treated fruit were gassed with ethylene as described below and monitoring of respiration, ethylene production, and fruit volatile production was resumed on day 12 and concluded on day 14. The control and 1-MCP-treated fruit not being monitored were used for destructive analyses. Destructive analyses were performed after $0,5,11$, and $14 \mathrm{~d}$ to measure ACO protein content and gene expression analysis as described below.

MEASUREMENTS OF RESPIRATION AND ETHYLENE PRODUCTION. The 1.9-L jars were ventilated with air at a flow rate of $30 \mathrm{~mL} \cdot \mathrm{min}^{-1}$, and held at $22^{\circ} \mathrm{C}$. A glass "tee" on the outlet line was fitted with a Teflon-lined half-hole septum (Alltech Assoc., Deerfield, Ill.) to create a port for withdrawal of gas samples. All the connecting gas lines were composed of Teflon-PFE (Cole-Parmer Instrument Co., Chicago). Fruit respiration was measured by withdrawing $0.1 \mathrm{~mL}$ of gas from the sampling port and injecting it into an infrared gas analyzer (model 225-MK3; Analytical Development Co., Hoddeson, England) operated in a flow-through mode with $\mathrm{N}_{2}$ as the carrier gas and a flow rate of $100 \mathrm{~mL} \cdot \mathrm{min}^{-1}$. Ethylene production was determined using gas chromatography (GC) as previously described (Mir et al., 2001). Ethylene and $\mathrm{CO}_{2}$ concentrations were calculated relative to a certified gas standard (Matheson Gas Products, Chicago) containing $0.979 \mu \mathrm{L} \cdot \mathrm{L}^{-1}$ ethylene, $4.85 \% \mathrm{CO}_{2}, 1.95 \% \mathrm{O}_{2}$ balanced with $\mathrm{N}_{2}$ as previously described (Mir et al., 2001). Respiration and ethylene production were monitored daily.

Ethylene TREATMent. On the eleventh day, the 1-MCP-treated fruit used for monitoring $\mathrm{CO}_{2}$, ethylene, and fruit volatile production were exposed to an ethylene concentration of $36 \mu \mathrm{L} \cdot \mathrm{L}^{-1}$ for $20 \mathrm{~h}$ by injecting $70 \mu \mathrm{L}$ pure ethylene (Matheson Gas Products, Chicago) into the jar headspace; the 1-MCP-treated fruit being held for destructive analyses received no ethylene treatment. During the ethylene treatment period, the inlets and outlets of the jars were closed off and ventilation arrested. Ethylene levels were verified by $\mathrm{GC}$ as described previously. $\mathrm{O}_{2}$ levels were not monitored during the treatment period, but at typical respiratory rates measured, would be expected to deplete $\approx 100 \mathrm{~mL}$ of the $\approx 380 \mathrm{~mL}$ of $\mathrm{O}_{2}$ resident in the system upon sealing, yielding a decline of $\approx 6 \mathrm{kPa}$ from the initial $21 \mathrm{kPa} \mathrm{O}_{2}$. After treatment, the jars were again ventilated to monitor respiration, ethylene evolution, and ester production. Respiration and ethylene production were monitored daily.

Measurement of volatile eSters of WhOle fruit. Ester measurement was by GC coupled with time-of-flight mass spectrometry (TOFMS). To sample volatile esters, solid phase micro-extraction (SPME) fibers (60- $\mu \mathrm{m}$ PDMS/DVB coating; Supelco Co., Bellefonte, $\mathrm{Pa}$.) were inserted into the glass sampling "tee" in the outlet line and exposed to the effluent gas stream of the ventilated $1.9-\mathrm{L}$ jars for $4 \mathrm{~min}$ and immediately transferred to the GC injection port and desorbed. Absorbed volatiles were 
desorbed from the fiber coating by inserting the SPME fiber through a predrilled septum (Thermogreen LB-2; Supelco Co.) and into a glass-lined, splitless injector port $\left(200^{\circ} \mathrm{C}\right)$ of a gas chromatograph (HP-6890; Hewlett Packard Co., Wilmington, Del.) equipped with a mass selective detector (Pegasus II; Leco, St. Joseph, Mich.). Conditions of GC separation and TOFMS analysis were as previously described (Song et al., 1997). Identification of volatile components was confirmed by comparison of collected mass spectra with those of authenticated chemical standards and reference spectra in a mass spectral library (NIST MS Search 1.5; National Institute for Standard Technology, Gaithersburg, Md.). Data are presented for only three compounds: hexyl acetate, butyl acetate, and 2-methylbutyl acetate, which were emitted in the largest amounts relative to other esters and were considered to contribute significantly to apple fruit aroma (Plotto et al., 2000). Quantization of volatile compounds was performed by calibrating with a known amount of an authenticated and high purity standard mixture as previously described (Song et al., 1997). Ester measurements were made on days $-1,0,1,2,5,7,9,11$, 12, and 14. All measurements were done in triplicate.

INCUBATION OF APPLE SLICES WITH ESTER PRECURSORS. 1-Butanol and butyric acid were purchased from a commercial source (Sigma-Aldrich, St. Louis). Five days after 1-MCP treatment, 1 - to 2 -mm-thick slices $(0.9 \mathrm{~g})$ of fruit skin and cortex from a pool of three fruit were cut and put on the surface of filter paper previously immersed in $1.0 \mathrm{~mL}$ of $0.1 \mathrm{~m}$ MES buffer $(\mathrm{pH}=7.0)$ containing $10^{-9}$ mol 1-butanol or $10^{-8}$ mol butyric acid. Each slice was sealed in a 30-mL glass vial fitted with a cap housing a valved septum (Mininert; Supelco Co.) for $120 \mathrm{~min}$ at $22{ }^{\circ} \mathrm{C}$. Volatile analysis was performed by using SPME/GC/TOFMS as described above. The effect of the addition of precursors was determined by calculating the ratio of ester concentration in vials without precursors to that of those with precursors. Measurements were conducted in triplicate.

Electrophoresis and immunoblotting of ACC-oxidase. Tissue samples were obtained on day 0 , day 5 , and day 11 for control and treated fruit. Total protein was extracted from apple tissue by using the method of Gorny and Kader(1996). The protein content of extracts for Western blot analysis was determined using the method of Bradford (1976). Twenty-five micrograms of total protein per lane were separated by SDS-PAGE as described by Laemmli (1970). Polyacrylamide gels (12\%) were stained with Coomassie blue, and were electroblotted onto a nitrocellulose membrane (Bio-Rad, Hercules, Calif.). The membrane was probed with ACO antibody (Neogen, Lansing, Mich.). Immuno-detection with the alkaline phosphatase reaction was carried out as described by Gorny and Kader (1996).

RNA ISOLATION, ELECTROPHORESIS, AND IMMUNOBLOTTING. Fruit disks taken from skin and $2-3 \mathrm{~mm}$ of underlying cortex tissue were frozen in liquid nitrogen and stored at $-80^{\circ} \mathrm{C}$. Five grams of tissue was ground into powder in liquid $\mathrm{N}_{2}$ using a mortar and pestle. Total RNA was extracted using the hot borate/phenol technique essentially as described by Lopez-Gomez and GomezLim (1992) and quantified spectrophotometrically. Northern analysis was essentially as described by Sambrook et al. (1989). Total RNA (25 $\mu \mathrm{g}$ per lane) was separated by electrophoresis in a $1.2 \%$ agarose gel containing $2.2 \mathrm{~m}$ formaldehyde in $20 \mathrm{~mm}$ MOPS running buffer. The $18 \mathrm{~S}$ and $28 \mathrm{~S}$ ribosomal bands were visualized using ethidium bromide fluorescence. After destaining, the gels were blotted onto nylon membranes (Hybond N; Amersham, Piscataway, N.J.), and fixed by exposure to ultraviolet radiation. $M d A C O 1$ (AF030859) and MdACS1 (L31347)
cDNA was labeled with [32P]dCTP by using a random-primer DNA labeling kit (Boehringer Mannheim, Basel, Germany) and hybridized to the membranes using routine procedures. The blots on the membrane were visualized by autoradiography using Kodak XAR-5 film (Kodak, Rochester, N.Y.) with an intensifying screen at $-80{ }^{\circ} \mathrm{C}$.

\section{Expt. 2}

Plant material. 'Jonagold' and 'Redchief Delicious' fruit were harvested on 23 Sept. and 5 Oct., respectively, in 2002 from commercial orchards in the Fruit Ridge area of Michigan north of Grand Rapids. Fruit were harvested prior to the onset of autocatalytic ethylene production as determined by the average internal ethylene level, which was below $0.2 \mu \mathrm{L} \cdot \mathrm{L}^{-1}$ for 10 randomly selected fruit. Internal ethylene levels were determined as previously described (Mir et al., 2001).

1-MCP TREATMENT. For each cultivar, the harvested fruit were divided into two groups of $\approx 220$ fruit and each group was placed into 113-L plastic barrels fitted with airtight lids. $\mathrm{O}_{2}$ levels were not monitored during the treatment period but typical respiratory activity for apple fruit would be expected to deplete $\approx 6 \mathrm{~L}$ of the $22 \mathrm{~L}_{\text {of }} \mathrm{O}_{2}$ resident in the system upon sealing, yielding a decline of $\approx 5$ to $6 \mathrm{kPa}$ from the initial $21 \mathrm{kPa} \mathrm{O}_{2}$. One barrel was used as a control and the second was used to treat fruit with 1-MCP. 1-MCP was generated using EthylBloc (Biotechnologies for Horticulture, Burr Ridge, Ill.) formulation (a.i. $=0.14 \%$ ) in an amount sufficient to create an initial concentration of $\approx 1 \mu \mathrm{L} \cdot \mathrm{L}^{-1}$. The EthylBloc was placed into four 1.5-mL microcentrifuge tubes and the 1-MCPreleased from the cyclodextrin matrix using $100 \mu \mathrm{L}$ of water added to the well of the tube cap. The tubes were sealed, and shaken for 2 to $3 \mathrm{~s}$ to mix the water with the cyclodextrin. The 1-MCP was administered by opening the microcentrifuge tubes in the treatment chambers and immediately closing the lid. The exposure period was $20 \mathrm{~h}$. 1-MCP concentrations were verified as previously described (Mir et al., 2001).

Storage TREatments. For 'Jonagold', treated and nontreated fruit were divided into 10 lots of 20 fruit each. Each lot was placed in a 20 -L plastic bucket fitted with an airtight lid having a 3-cm-diameter hole. The hole was left open for air-stored fruit, or plugged with a rubber stopper pierced by inlet and exit lines for $\mathrm{CA}$-stored fruit. From treated and nontreated fruit, one lot was left to ripen at room temperature $\left(22^{\circ} \mathrm{C}\right)$, six lots were placed in RA storage at $0{ }^{\circ} \mathrm{C}$ for $1,2,3,4,5$, and 7 months and the remaining three lots were placed in CA storage $\left(1.5 \mathrm{kPa} \mathrm{O}_{2}\right.$ and $\left.\leq 3 \mathrm{kPa} \mathrm{CO}_{2}\right)$ at $0{ }^{\circ} \mathrm{C}$ for 2,4 , and 7 months. CA conditions were established using $\mathrm{N}_{2}$ gas from a nitrogen generator (CPA-1; Permea, St. Louis) and blending it with $\mathrm{O}_{2}$ contained in compressed air and gaseous $\mathrm{CO}_{2}$ from a liquified $\mathrm{CO}_{2}$ (Linde Gas, Independence, Ohio) source. Gas concentrations were established manually. Pressure was maintained using two-stage regulators and flow was adjusted using needle valves. Blended gas was humidified by first bubbling the gas into water contained in a 20 -L glass jar in the cold room where the fruit were stored. The humidified gas was then directed to a flow board external to the cold room to avoid problems with condensation and distributed to individual lines using a manifold outfitted with glass capillary tubes. Gas flow from the flow boards was returned to the cold room and into the 20 -L plastic buckets containing fruit and was maintained at $\approx 75$ $\mathrm{mL} \cdot \mathrm{min}^{-1}$. For 'Redchief Delicious,' treated and nontreated fruit were divided into six lots of 20 fruit each. One lot was kept at 22 ${ }^{\circ} \mathrm{C}$; the other lots were placed in RA storage and held at $0{ }^{\circ} \mathrm{C}$ for $2,3,4,5$, and 7 months as described previously for 'Jonagold'. 
Volatile ANALYSIS. Volatile analysis was performed on fruit immediately after harvest and after storage by holding the fruit at room temperature $\left(22^{\circ} \mathrm{C}\right)$ and monitoring volatile production until senescence was extensive based on external appearance (yellowing and greasiness). The volatile profile of 'Jonagold' fruit was analyzed after $0,1,2,3,4,5$, and 7 months of storage in RA and after 2, 4, and 7 months in CA. The volatile profile of 'Redchief Delicious' fruit was analyzed after 0, 2, 3, 4, 5, and 7 months in RA. On each analysis date, one lot each of control and 1 -MCP-treated fruit was removed from the storage. From these, three fruits were placed singly into 1-L Teflon chambers (Savillex Corp, Minnetonka, Minn.) fitted with gas sampling ports as in Expt. 1. The remaining fruit were held in a similar condition and used to replace fruit if any were lost to decay during the poststorage holding period. Chambers were ventilated at a rate of $\approx 35$ $\mathrm{mL} \cdot \mathrm{min}^{-1}$ with purified air and held at room temperature $\left(22^{\circ} \mathrm{C}\right)$ between 25 to $95 \mathrm{~d}$. Volatile emissions were measured once or twice weekly, depending on the rate of fruit deterioration. Volatile analysis was by SPME/GC/TOFMS as described for Expt. 1. For each sample, volatile emissions were represented using the total ion count (TIC) for all volatiles combined excluding $\mathrm{CO}_{2}$. The TIC is the sum of all ions detected between $\mathrm{m} / \mathrm{z} 29$ and $\mathrm{m} / \mathrm{z} 600$ with background noise subtracted. The time required for volatile production to begin was determined as the date after which the TIC was greater than $1 \times 10^{8}$, which was subjectively chosen as a threshold since it is $\approx 20 \%$ of the peak amount detected for the treatment with the lowest peak volatile production. In addition to volatile analysis, the internal ethylene concentration of 10 representative fruit was measured on each removal date after fruit had warmed to room temperature as previously described for Expt. 1.

Statistical analysis. To objectively estimate the date of the peak in volatile formation and the relative amount of volatile formation, the data were fitted with an appropriate equation using commercial curve-fitting software (Table Curve 2D; Jandel Scientific, San Rafael, Calif.). A $t$ test was performed using statistical software (SigmaStat 3.11; Systat Software, Point Richmond, Calif.) to compare nontreated and 1-MCP treated fruit for RA- and CA-stored fruit using estimates of the peak in volatile synthesis provided by the fitted curves.

\section{Results}

\section{Expt. 1}

EFFECT OF 1-MCP ON RESPIRATION AND ETHYLENE BIOLOGY. The climacteric increase of respiration and ethylene production for nontreated fruit began $\approx 4-5 \mathrm{~d}$ after harvest (Fig. $1 \mathrm{~A}$ and $\mathrm{B}$ ). The initial increase in ethylene synthesis and $\mathrm{CO}_{2}$ production was prevented by 1-MCP and, for the remainder of the 11-d monitoring period, respiration and ethylene production by fruit treated with 1-MCP remained at or below preclimacteric levels. Application of exogenous ethylene on day 11 to 1-MCP-treated fruit did not induce an increase in fruit respiration or ethylene production. Expression of MdACO and MdACS increased and the protein content of ACO increased on day 5 for control fruit, changing simultaneously with the increase in ethylene biosynthesis (Figs. 2 and 3). ACO content remained high at day 11. Relative to controls, 1-MCP treatment suppressed MdACS1 and MdACOI expression measured on day 5 and ACO formation measured on day 5 and day 11. Exogenous ethylene applied $11 \mathrm{~d}$ after 1-MCP treatment did not induce an increase in expression of MdACS1 or MdACO1 relative to control fruit by day 14 .

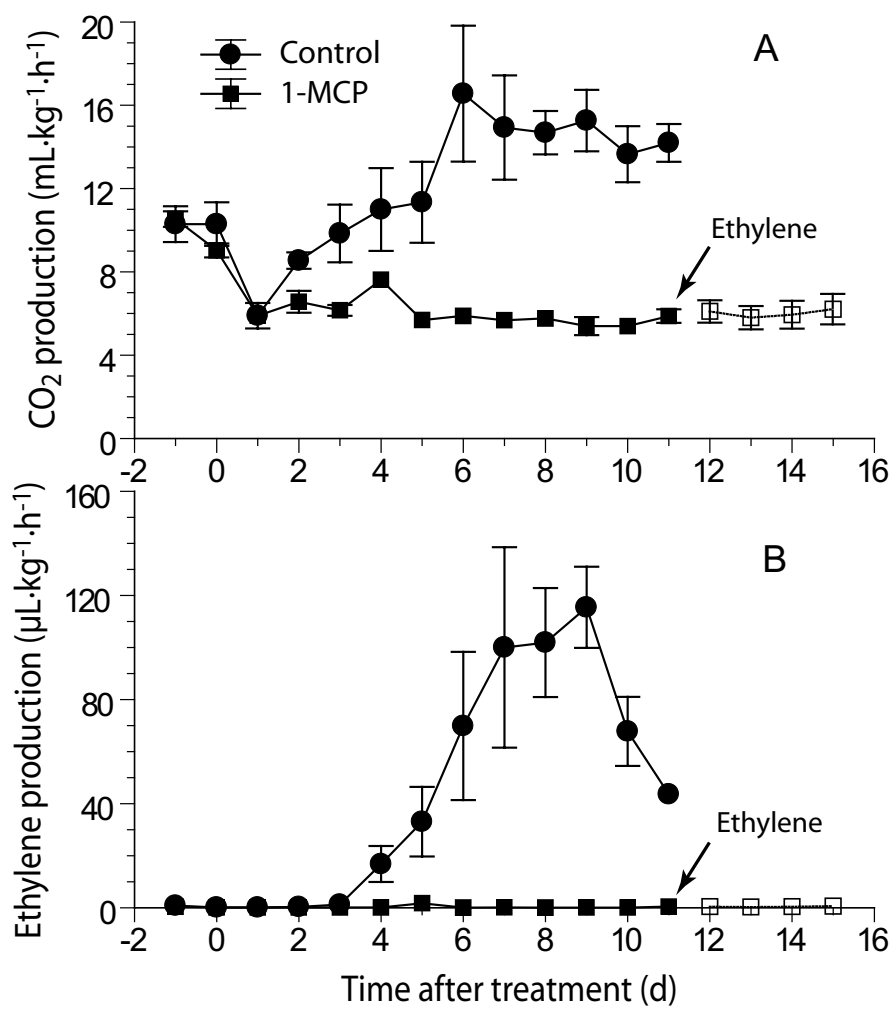

Fig. 1. Respiration (A) and ethylene production (B) of 'Golden Delicious' apple fruit treated with $1-\mathrm{MCP}$ and held in air at $22{ }^{\circ} \mathrm{C}$. Arrow indicates treatment of 1-MCP-treated fruit with ethylene. Vertical bars represent mean \pm standard deviation, $\mathrm{n}=3$.

EFFECT OF 1-MCPON FRUIT ESTER PRODUCTION AND BIOSYNTHESIS. In control fruit, volatile production of straight and branched chain esters started to increase $\approx 5 \mathrm{~d}$ after treatment (Fig. 4A-C). 1 -MCP prevented this increase, with all volatiles declining from initial levels and maintaining extremely low production rates during the $11 \mathrm{~d}$ of the experiment and for $3 \mathrm{~d}$ following the application of exogenous ethylene on day 11 . However, the exogenously applied precursors 1-butanol and butyric acid were preferentially converted into their corresponding volatile esters (i.e., 1-butanol into butyl acetate and butyric acid into ethyl butanoate) despite inhibition of ripening and volatile synthesis for 1-MCP-treated fruit on day 5 (Table 1). The incorporation of 1-butanol and butyric acid into butyl butanoate was much greater than into butyl acetate and ethyl butanoate.

\section{Expt. 2}

1-MCP and CA conditions reduced ethylene production of both 'Jonagold' and 'Redchief Delicious' apple fruit (data not shown). The internal ethylene content in 1-MCP-treated fruit was less than $1 \%$ that in nontreated fruit upon removal from storage for all assay dates. While more than 50 individual volatile compounds were detected in chromatograms of ripening fruit, most of these were esters. When the TIC was summed for all volatiles in the profile, excluding $\mathrm{CO}_{2}$, esters and their acid and alcohol precursors accounted for $\approx 90 \%$ to $95 \%$ of the total. The sesquiterpene $\alpha$-farnesene accounted for nearly all the remainder, although several other compounds, including 6-methyl-5-hepten-2-one and 1-methoxy-4-(2-propenyl)-benzene were also detected. The sum of the TIC for all volatiles excluding $\mathrm{CO}_{2}$ was used to evaluate the effect of 1-MCP on total volatile synthesis, recognizing that individual compounds may have different developmental patterns. 


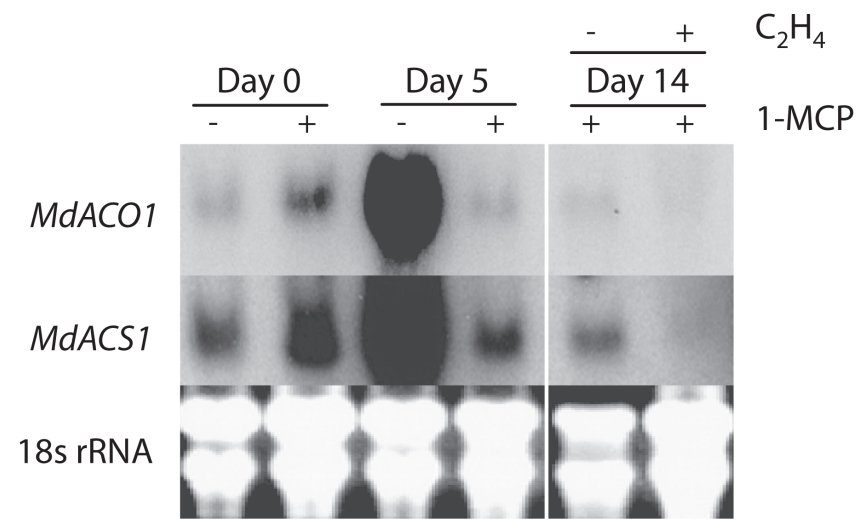

Fig. 2. Northern blot analysis for ACC oxidase (MdACO) and ACC synthase (MdACS1) of 'Golden Delicious' apple fruits treated with 1-MCP on day -1 and held in air at $22{ }^{\circ} \mathrm{C}$. Assays were conducted 0,5 , and $14 \mathrm{~d}$ after 1-MCP treatment (sample on day 11 was lost); fruit assayed on d 14 were treated with $36 \mu \mathrm{L} \cdot \mathrm{L}^{-1}$ ethylene for $20 \mathrm{~h}$ or were left untreated. Total RNA ( $25 \mu \mathrm{g} /$ lane $)$ was separated by formaldehyde agarose gel electrophoresis and blots were analyzed by hybridization to the [ $\left.{ }^{32} \mathrm{P}\right] \mathrm{dCTP}$-labeled pAAS2 MdACO probe and MdACS1 probe. The18S rRNA was visualized using ethidium bromide staining as a measure of loading uniformity.

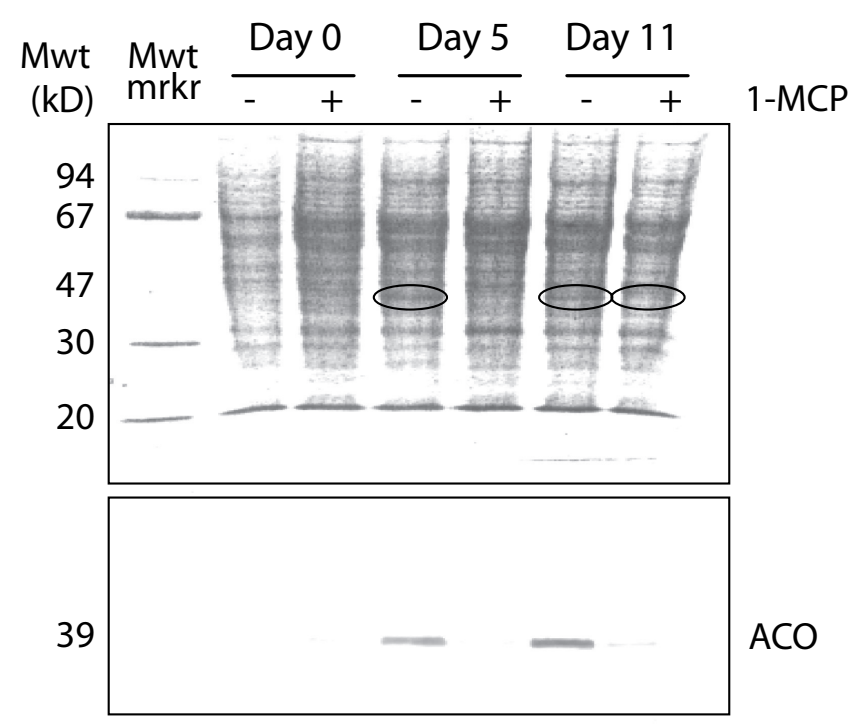

Fig. 3. Western blot analysis of ACO of 'Golden Delicious' apple fruit treated with 1 -MCP on day -1 and held in air at $22^{\circ} \mathrm{C}$. Assays were conducted 0,5 , and $11 \mathrm{~d}$ after 1-MCP treatment. Proteins ( $25 \mu \mathrm{g} / \mathrm{lane})$ were separated by sodium dodecyl (lauryl) sulfate-polyacrylamide gel (SDS-PAGE) (upper figure) and transferred to a nylon membrane and detected with ACC oxidase (ACO) antibody (lower figure). The ACO bands have an approximate molecular weight (Mol wt) of $39 \mathrm{kD}$ as determined by biotinylated molecular weight markers (Mol wt mrkr); their approximate location is indicated on the SDS-PAGE by ellipses.

Generally, however, when ester content was low, other volatiles were also low or nondetectable (data not shown).

The data describing the pattern in volatile production for airand CA-stored fruit, with and without 1-MCP treatment, could be empirically fit by several of the equations provided by the curve-fitting software. Of these, those equations having constants that could be used to gather physiologically relevant data such as the timing of the peak in volatile formation and its maximum were evaluated further. Of these, the equation providing the best fit for all 'Jonagold' and 'Redchief Delicious' profiles was: TIC $=a \times \exp (-\exp (-((x-b) / c))-((x-b) / c)+1)$, where $x$ is the number of days holding at $22^{\circ} \mathrm{C}$ after removal from RA or CA storage. The value of $a$ was used to obtain an objective estimate of the maxi-
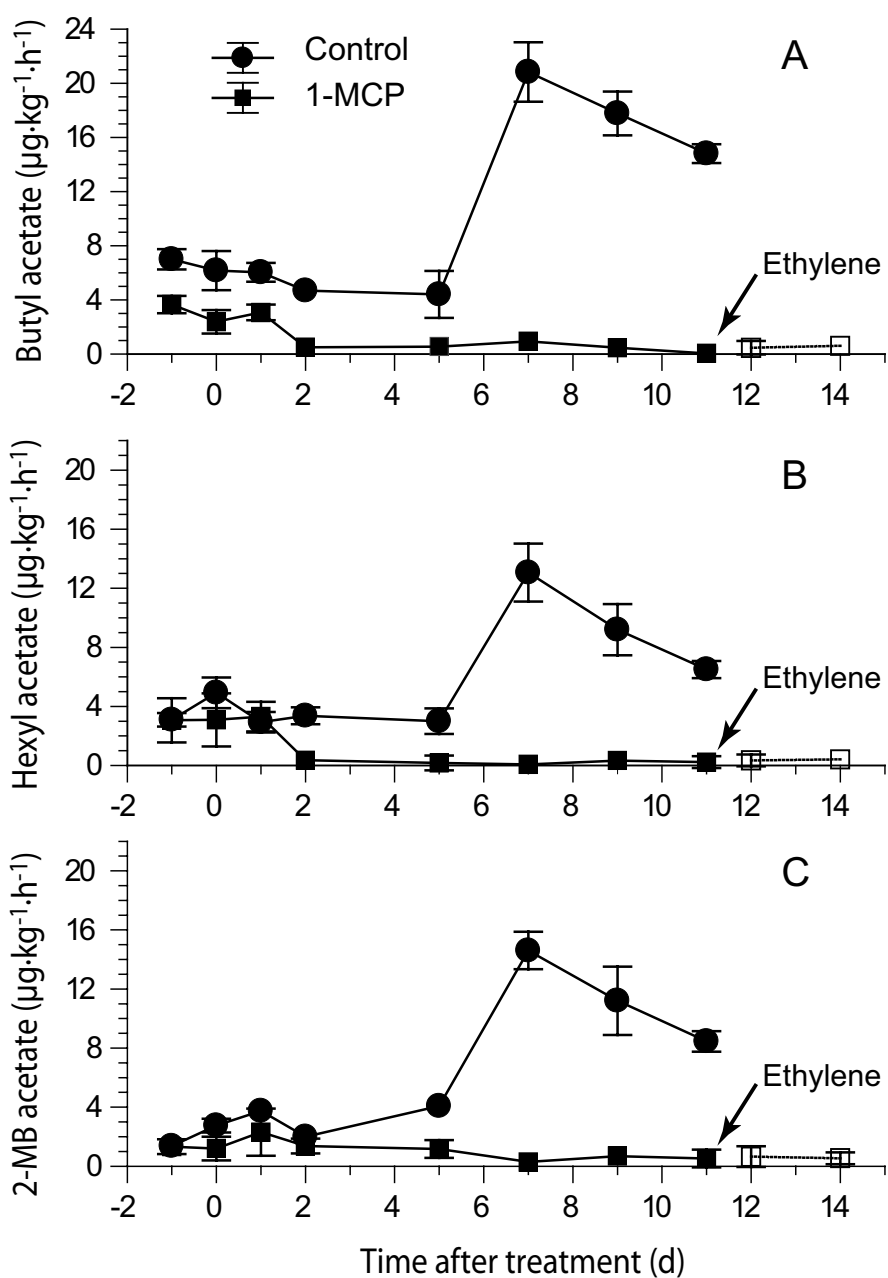

Fig. 4. Production of volatile aroma compounds of 'Golden Delicious' apple fruit treated with 1-MCP on day -1 and held in air at $22{ }^{\circ} \mathrm{C}$. (A) butyl acetate, (B) hexyl acetate, and (C) 2-methylbutyl (2-MB) acetate. Arrow indicates treatment of 1-MCP-treated fruit with ethylene. Vertical bars represent mean \pm standard deviation; $\mathrm{n}=3$.

Table 1. Ratio of esters formed by the application of aroma precursors 1-butanol and butyric acid relative to untreated tissues for tissue disks of 'Golden Delicious' apple fruit $5 \mathrm{~d}$ after fruit were treated with $1-\mathrm{MCP}$. Values represent the ratio between treatments and control fruit $(n=3) \pm$ SD.

\begin{tabular}{lrr}
\hline & \multicolumn{2}{c}{ Ester precursor } \\
\cline { 2 - 3 } Ester & 1 1-butanol & \multicolumn{1}{c}{ butyric acid } \\
\hline ethyl butanoate & $1.1 \pm 0.2$ & $1.8 \pm 0.5$ \\
butyl acetate & $2.1 \pm 0.2$ & $1.5 \pm 0.3$ \\
butyl butanoate & $147.3 \pm 2.5$ & $102.9 \pm 4.7$ \\
hexyl acetate & $4.1 \pm 1.2$ & $2.0 \pm 1.1$ \\
\hline
\end{tabular}

mum TIC for fruit volatiles and that of $b$ to estimate the day of the maximum; the relationship between the value of $c$ and curve shape was not evident.

Nontreated 'Jonagold' fruit began synthesizing volatiles immediately after harvest while 1-MCP-treated fruit required $\approx 25$ d (Fig. 5). Volatile production peaked after $\approx 14 \mathrm{~d}$ at room temperature for nontreated fruit, while for those treated with 1-MCP peak volatile synthesis required more than $50 \mathrm{~d}$ (Table 2). For 'Redchief Delicious', nontreated fruit began volatile formation after $5 \mathrm{~d}$ at room temperature, but 1-MCP delayed the onset of 


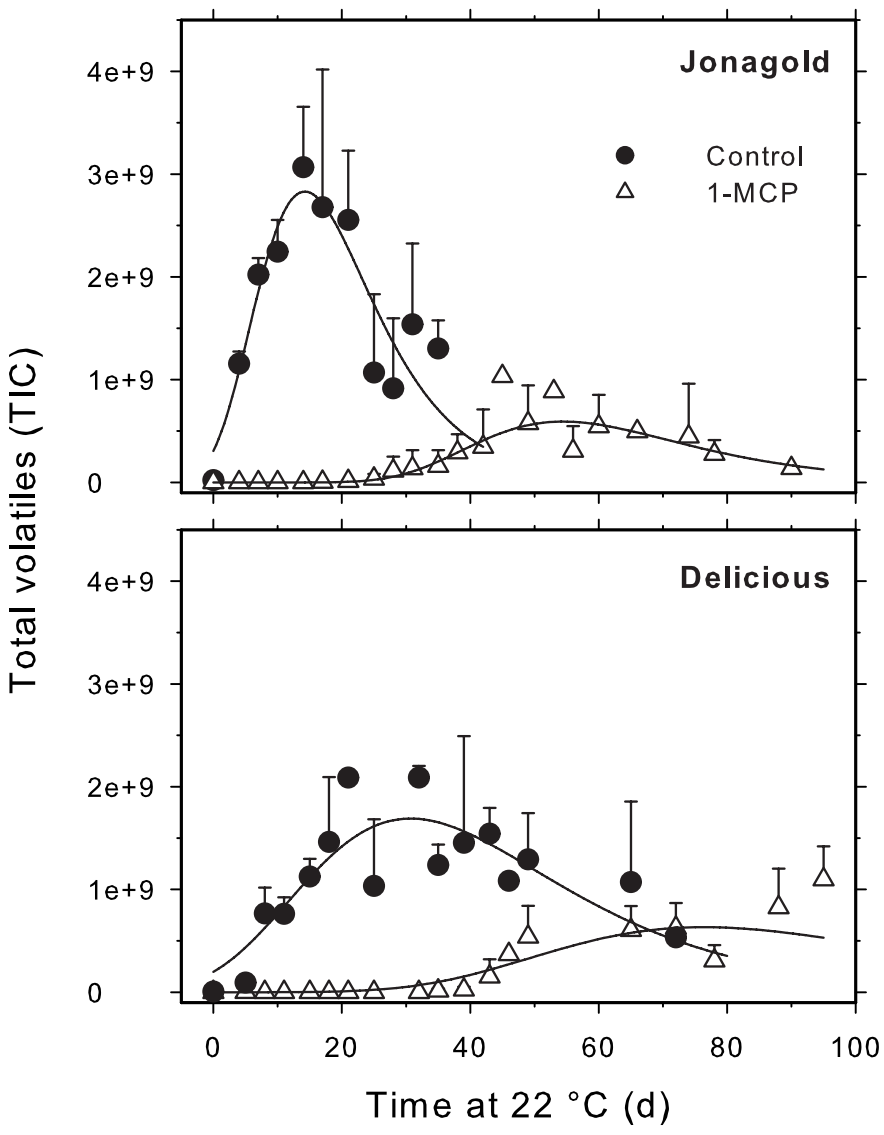

Fig. 5. Total ion count (TIC) for volatiles produced by 'Jonagold' and 'Redchief Delicious' apple fruit treated with $1 \mathrm{~mL} \cdot \mathrm{L}^{-1} 1$-MCP (open triangles) or left nontreated as controls (solid circles) immediately after harvest while being held at $22{ }^{\circ} \mathrm{C}$.

the increase in volatile synthesis until after $40 \mathrm{~d}$. The peak in volatile biosynthesis took place after $\approx 30$ and $75 \mathrm{~d}$ of holding for nontreated and treated fruit, respectively. The maximal level of volatile formation was reduced by $50 \%$ or more by 1 -MCP for both cultivars (Table 2).

After 1 month in RA storage at $0{ }^{\circ} \mathrm{C}$, nontreated 'Jonagold' fruit were already producing moderate amount of volatiles at the time of removal, while 1-MCP-treated fruit had essentially no volatile production (Fig. 6). Volatile synthesis increased for 1$\mathrm{MCP}$-treated fruit after $30 \mathrm{~d}$ poststorage holding at $22^{\circ} \mathrm{C}$. Aroma production peaked after $\approx 2$ weeks for nontreated fruit and after 60 $\mathrm{d}$ for fruit treated with 1-MCP (Table 2). As the duration of cold storage increased, the poststorage delay in volatile production caused by 1-MCP declined (Fig. 6). After 5 months RA storage, 'Jonagold' fruit treated with 1-MCP were producing low levels of volatiles at the time of removal from storage. Similarly, the poststorage holding time until peak volatile synthesis occurred also declined (Fig. 6, Table 2). Results were similar for 'Redchief Delicious' fruit with the nontreated fruit producing significant quantities of volatiles upon removal from RA for all storage durations ( 1 month data are lacking) and treated fruit experiencing a poststorage delay in volatile synthesis that declined from 20 $\mathrm{d}$ at 2 months RA to $0 \mathrm{~d}$ after 5 months (Fig. 7). For nontreated fruit, the pattern of volatile formation during poststorage holding differed markedly for the two cultivars. For 'Jonagold' fruit, the initial level of volatile formation was relatively similar for the entire 7 months RA storage, however, the quantity of volatiles
Table 2. Coefficient of determination and constants $a, b$, and $c$ for equation fitted to volatile production data of 'Jonagold' and 'Redchief Delicious' apple fruit treated with $1 \mu \mathrm{L} \cdot \mathrm{L}^{-1} 1-\mathrm{MCP}(\mathrm{Y})$ or left nontreated (N) as controls following 0 to 7 months storage in refrigerated air (RA) or controlled atmosphere (CA) $\left(1.5 \mathrm{kPa} \mathrm{O}_{2}, 3 \mathrm{kPa} \mathrm{CO}_{2}\right)$ storage at 0 ${ }^{\circ} \mathrm{C}$. Equation: mass spectrometer total ion count $=a \times \exp (-\exp (-((x-$ $b) / c))-((x-b) / c)+1)$, where $x$ is the number of days holding at $22^{\circ} \mathrm{C}$ after removal from RA or CA storage. The value of $a$ represents the maximum and that of $b$ depicts the day of the maximum; the relationship between the value of $c$ and curve shape is unclear.

\begin{tabular}{|c|c|c|c|c|c|}
\hline \multicolumn{2}{|c|}{ Treatments } & \multirow[b]{2}{*}{$R^{2}$} & \multicolumn{3}{|c|}{ Values for constants } \\
\hline Month & 1-MCP & & $a$ & $b$ & $c$ \\
\hline & & \multicolumn{4}{|c|}{ Jonagold (RA storage) } \\
\hline 0 & $\mathrm{~N}$ & 0.81 & $2.83 \mathrm{E}+09$ & 14.24 & 9.09 \\
\hline 0 & $\mathrm{Y}$ & 0.85 & $5.92 \mathrm{E}+08$ & 54.43 & 16.49 \\
\hline 1 & $\mathrm{~N}$ & 0.14 & $2.73 \mathrm{E}+09$ & 13.08 & 17.13 \\
\hline 1 & $\mathrm{Y}$ & 0.96 & $9.84 \mathrm{E}+08$ & 60.98 & 14.41 \\
\hline 2 & $\mathrm{~N}$ & 0.93 & $2.67 \mathrm{E}+09$ & 12.48 & 12.99 \\
\hline 2 & $\mathrm{Y}$ & 0.99 & $1.38 \mathrm{E}+09$ & 39.56 & 8.31 \\
\hline 3 & $\mathrm{~N}$ & 0.90 & $2.21 \mathrm{E}+09$ & 10.34 & 16.21 \\
\hline 3 & Y & 0.84 & $9.24 \mathrm{E}+08$ & 54.01 & 21.75 \\
\hline 4 & $\mathrm{~N}$ & 0.98 & $8.36 \mathrm{E}+10$ & -71.12 & 15.73 \\
\hline 4 & Y & 0.92 & $7.75 \mathrm{E}+08$ & 37.09 & 19.09 \\
\hline 5 & $\mathrm{~N}$ & 0.84 & $2.64 \mathrm{E}+09$ & 3.86 & 13.85 \\
\hline 5 & $\mathrm{Y}$ & 0.86 & $9.68 \mathrm{E}+08$ & 27.23 & 15.02 \\
\hline 7 & $\mathrm{~N}$ & 0.98 & $2.39 \mathrm{E}+09$ & 10.41 & 15.70 \\
\hline \multirow[t]{2}{*}{7} & Y & 0.89 & $1.34 \mathrm{E}+09$ & 29.62 & 15.08 \\
\hline & & \multicolumn{4}{|c|}{ Jonagold (CA storage) } \\
\hline 2 & $\mathrm{~N}$ & 0.72 & $1.36 \mathrm{E}+09$ & 21.13 & 13.73 \\
\hline 2 & Y & 0.70 & $5.01 \mathrm{E}+08$ & 52.72 & 15.85 \\
\hline 4 & $\mathrm{~N}$ & 0.69 & $1.26 \mathrm{E}+09$ & 16.49 & 12.46 \\
\hline 4 & Y & 0.97 & $9.01 \mathrm{E}+08$ & 47.23 & 10.88 \\
\hline 7 & $\mathrm{~N}$ & 0.85 & $8.43 \mathrm{E}+08$ & 18.72 & 12.45 \\
\hline \multirow[t]{2}{*}{7} & Y & 0.99 & $5.43 \mathrm{E}+08$ & 45.45 & 10.33 \\
\hline & & \multicolumn{4}{|c|}{ Redchief Delicious (RA storage) } \\
\hline 0 & $\mathrm{~N}$ & 0.71 & $1.69 \mathrm{E}+09$ & 30.70 & 19.85 \\
\hline 0 & $\mathrm{Y}$ & 0.81 & $6.33 \mathrm{E}+08$ & 76.34 & 28.33 \\
\hline 2 & $\mathrm{~N}$ & 0.89 & $2.30 \mathrm{E}+09$ & 0.71 & 22.80 \\
\hline 2 & Y & 0.76 & $5.18 \mathrm{E}+08$ & 46.98 & 20.42 \\
\hline 3 & $\mathrm{~N}$ & 0.81 & $1.87 \mathrm{E}+09$ & 6.62 & 22.37 \\
\hline 3 & Y & 0.85 & $9.23 \mathrm{E}+08$ & 48.07 & 21.62 \\
\hline 4 & $\mathrm{~N}$ & 0.63 & $9.72 \mathrm{E}+08$ & 5.62 & 13.95 \\
\hline 4 & Y & 0.71 & $1.17 \mathrm{E}+09$ & 50.94 & 26.09 \\
\hline 5 & $\mathrm{~N}$ & 0.59 & $2.85 \mathrm{E}+10$ & -239 & 54.99 \\
\hline 5 & Y & 0.72 & $1.59 \mathrm{E}+09$ & 38.54 & 25.27 \\
\hline 7 & $\mathrm{~N}$ & 0.02 & $6.01 \mathrm{E}+08$ & -777.90 & 694.40 \\
\hline 7 & $\mathrm{Y}$ & 0.59 & $1.09 \mathrm{E}+09$ & 25.39 & 18.76 \\
\hline
\end{tabular}

produced by 'Redchief Delicious' fruit declined by roughly $80 \%$ by 7 months.

In the case of 'Jonagold' fruit stored under CA conditions, nontreated fruit began to produce a moderate quantity of volatiles immediately after removal from storage for all three storage durations (Fig. 8). However, $\approx 30 \mathrm{~d}$ at room temperature passed before 1-MCP-treated fruit recovered the capacity to produce volatiles after 2 months in CA. After 4 and 7 months in CA, volatile formation began after $\approx 25 \mathrm{~d}$ at room temperature. Peak volatile formation required $\approx 50 \mathrm{~d}$ of poststorage holding for all CA storage durations (Table 2).

1 -MCP reduced maximum volatile biosynthesis $(P<0.05)$ of RA-stored 'Jonagold' and 'Redchief Delicious' fruit (Figs. 6 and 7, Table 2). The average maximum TIC observed in nontreated 

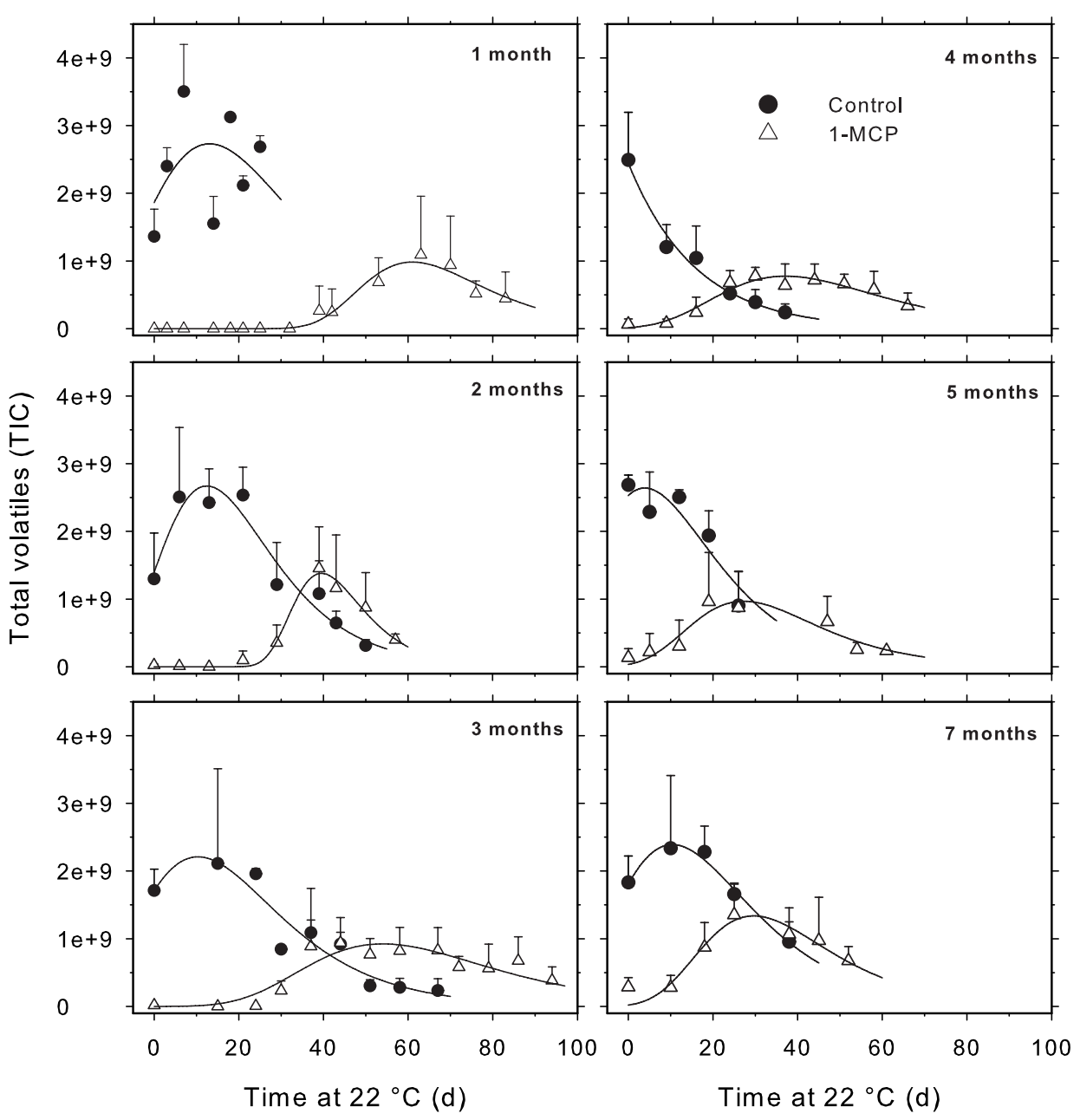

Fig. 6. Total ion count (TIC) for volatiles produced by 'Jonagold' apple fruit treated with $1 \mathrm{~mL} \cdot \mathrm{L}^{-1} 1-\mathrm{MCP}$ (open triangles) or left nontreated as controls (solid circles) following refrigerated air storage $\left(0{ }^{\circ} \mathrm{C}\right)$ for $1,2,3,4,5$, or 7 months while being held at $22^{\circ} \mathrm{C}$.

'Jonagold' fruit stored in RA was $2.73 \times 10^{9}$ while for treated fruit, the average maximum was $1.04 \times 10^{9}(\approx 62 \%$ lower than nontreated fruit). In the case of fruit stored under CA conditions, there was no statistically significant effect of $1-\mathrm{MCP}$ on the maximum level of volatile production. The average maximum GC/MS response observed in nontreated fruit under CA conditions was $1.54 \times 10^{9}$ counts, a value close to the one obtained in fruit treated with 1-MCP and stored under RA conditions. Treated fruit under CA conditions had an average peak of $9.20 \times 10^{8}$ counts.

The data from Table 2 for the delay to onset of volatile formation and the delay to peak production were fitted with the same equation used to describe volatile formation (Fig. 9). The data were insufficient for trend analysis, so values for the constants of the fitted curves are not presented. However, the curves were useful for visualizing the data. The delay to the onset of volatile formation declined in what appeared to be a sigmoidal fashion, remaining steady or increasing slightly initially in storage, then declining. The decline appeared to be slightly more rapid for 'Jonagold' than for 'Redchief Delicious' fruit. The pattern for the delay to the peak in volatile biosynthesis appeared to be more linear than that for the delay to onset for 1-MCP-treated fruit (Fig. 9). The delay to the peak in volatile formation for nontreated fruit declined for RA-stored fruit, but remained relatively constant for CA-stored fruit.

\section{Discussion}

The preclimacteric and climacteric rates of $\mathrm{CO}_{2}$ production reported are similar to those reported previously (Hulme, 1954; Hulme et al., 1963; Jones et al., 1965; Looney, 1969). Ethylene production rates are similarly consistent with previous research (Saftner et al., 2003). The reduction in the biosynthesis of ethylene, $\mathrm{CO}_{2}$, and total volatiles by $1-\mathrm{MCP}$ treatment is consistent with previous assertions that the climacteric rise in ethylene formation, $\mathrm{CO}_{2}$ synthesis, and volatile ester production in climacteric tissues is an ethylene-dependent process (Burg and Burg, 1962; Defilippi et al., 2005; Fan et al., 1998; Golding et al., 1999; Saftner, et al., 2003; Song and Bangerth, 1996). In the present study, effective inhibition of climacteric ethylene biology in 'Golden Delicious' fruit by 1-MCP and the consequent continued suppression of ethylene-related gene expression, and ethylene, $\mathrm{CO}_{2}$, and volatile production increases are consistent with previous reports (Abdi et al., 1998; Defilippi et al., 2005; Fan and Mattheis, 1999; Fan et al., 1999; Golding et al., 1998; Lurie etal., 2002). The effect of 1-MCP treatment on 'Golden Delicious' apple fruit in this experiment was not reversed in the short-term by exogenously applied ethylene, indicating that the effects on respiration and volatile synthesis were related to ethylene perception and not lack of ethylene presence, again consistent with known climacteric responses to ethylene action (Burg and Burg, 1962; Defilippi et al., 2005).

The pathway for ester formation is partially described and the final step has been relatively well characterized (Defilippi et al., 2005; Fellman et al., 2000). The extensive incorporation of exogenously applied precursors into esters indicates that 1MCP treatment did not completely arrest AAT activity, which is required for ester biosynthesis. This suggests that the final step in ester biosynthesis, which is carried out by a family of AAT enzymes, is not under the complete control of ethylene and that a significant portion of the control of ester formation by ethylene is at the level of precursor formation. This suggestion is consistent with the detection of significant AAT activity in preclimacteric and 1-MCP-treated 'Greensleeves' apple fruit that were not actively synthesizing esters (Defilippi et al., 2005). Defilippi et al. (2005) showed that gene expression of one member of the $A A T$ family ( $m d A A T 2$ ) was detectable prior to ripening, although AAT activity and $m d A A T 2$ gene expression both increased following the onset of ripening in this study. Souleyre et al. (2005) demonstrated a clone of $A A T$ in apple ( $M p A A T 1)$, fully characterized at the protein level to confer ester-forming capacity, to be present throughout fruit development. The supply of ester precursors was also considered the limiting factor for apple fruit harvested at the 


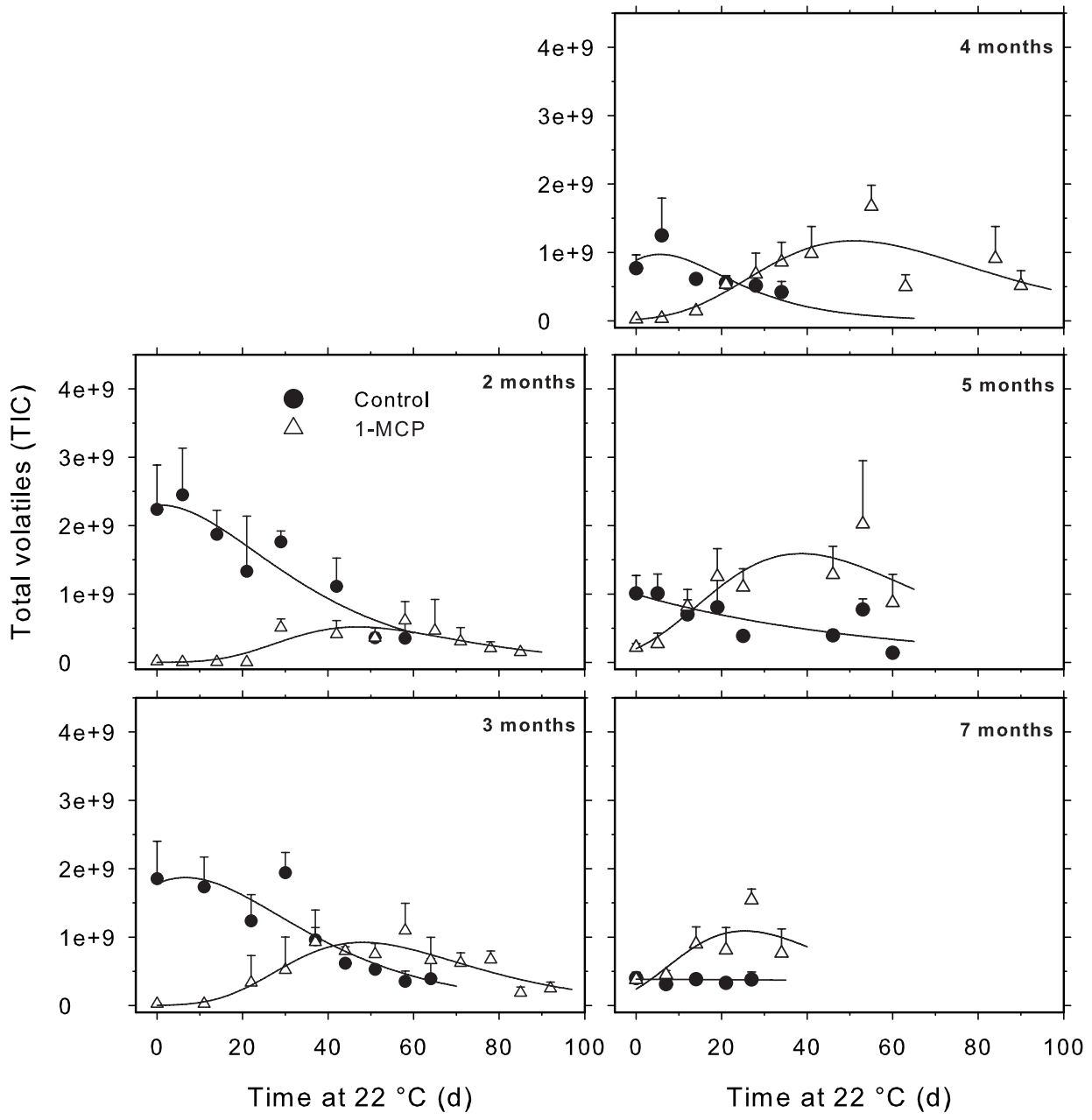

Fig. 7. Total ion count (TIC) for volatiles produced by 'Redchief Delicious' apple fruit treated with $1 \mathrm{~mL} \cdot \mathrm{L}^{-1} 1-\mathrm{MCP}$ (open triangles) or left nontreated as controls (solid circles) following refrigerated air storage $\left(0{ }^{\circ} \mathrm{C}\right)$ for $2,3,4$, 5 , or 7 months while being held at $22^{\circ} \mathrm{C}$.

preclimacteric stage and stored under CA conditions (Bartley et al., 1985; Brackmann et al., 1993). The presence of preclimacteric ester forming capacity and substrate limitation is also found in banana (Musa L., AAA group, Cavendish subgroup. cv. Valery), for which one $A A T$ clone (gi:10187178) in banana and in vivo AAT activity were readily detectable well in advance of the onset of fruit ripening although activity and gene expression both increased with ripening (Jayanty et al., 2004)

It is interesting that the application of either alcohol (1-butanol) or acid (butyric acid) enhanced ester formation in 1-MCP-treated fruit given that only one of two co-substrates was added at a time. Evidently, the capacity existed in the nonripening tissue to synthesize or otherwise make available a small amount of complementary two-carbon acid or alcohol co-substrates to make the esters ethyl butanoate and butyl acetate despite little to no active ester biosynthesis in the native tissue. The relatively high production rate of butyl butanoate in response to the addition of either butanol or butyric acid indicates that the enzymatic capacity to interconvert alcohol and acid precursors existed in the tissue, again suggesting that much of the machinery for ester biosynthesis (e.g., alcohol dehydrogenase, aldehyde dehydrogenase, and alcohol acyl transferase) is in place and active in nonripening tissue. Finally, the induction of hexyl acetate by the addition of butyl substrates of AAT is intriguing given that neither the acetate or hexanol co-substrates needed for its formation were provided. Hexyl acetate induction by both butanol and butanoic acid may reflect a sensitivity of the ester synthesis pathway to pathway activity.

The duration of the effect of 1-MCP on delaying the initiation of ethylenedependent ripening is a function of the crop species, ripening stage, storage temperature, the presence of ethylene or ethylene analogues, the duration of the 1-MCP treatment, and the concentration of the 1-MCP. Ripening inhibition by response-saturating levels of 1-MCP (or diazocyclopentadiene) has been reported to last $5-15 \mathrm{~d}$ for tomato (Lycopersicon esculentum Mill.) fruit (Mir et al., 2004; Nakatsuka et al., 1997; Sisler and Serek, 1997; Tian et al., 1997) and 12-25 d for banana fruit (Golding et al., 1998). In apple, Mir et al. (2001) demonstrated that the inhibition of fruit softening for 'Redchief Delicious' by a single dose of 1 -MCP lasted $\approx 20$ to $40 \mathrm{~d}$ at $20^{\circ} \mathrm{C}$ and $\approx 100 \mathrm{~d}$ at $0^{\circ} \mathrm{C}$. The findings in the current study for the delay in volatile formation at 22 and $0^{\circ} \mathrm{C}$ are consistent with these time scales. Repeated or continuous doses of 1-MCP at levels that saturated its response appeared to arrest indefinitely some aspects of ripening in tomato and apple (Jayanty et al., 2004; Mir et al., 2004). As the duration of the 1-MCP treatment increased, the delay in the onset of ripening increased for tomato (Mir et al., 2004) The impact of 1-MCP treatment duration on the recovery period for apple ripening is not known.

The effects of 1-MCP treatment on delaying the onset and reducing the rate of volatile production in apple fruit at 0 months RA storage were similar to the effects found for banana (Golding et al., 1998, 1999) and apple (Kondo et al., 2005) fruit. The delay in the recovery of volatile biosynthesis for 'Delicious' and 'Golden Delicious' apple held at $20^{\circ} \mathrm{C}$ was reported to be $\approx 21$ and $14 \mathrm{~d}$, respectively (Kondo, et al., 2005). This agrees reasonably well with the delay of $\approx 25$ and $40 \mathrm{~d}$, respectively, for 'Jonagold' and 'Redchief Delicious' fruit in the current study. The greater duration of 1-MCP effectiveness in the current study may be related to the influence of cultivar or differences in fruit maturity at the time of treatment. In the cited study, internal ethylene levels at the time of treatment were $\approx 5$ - to 20 -fold higher than in the current study.

The 1-MCP-induced delay in the recovery of volatile synthesis for apple fruit stored at low temperature $\left(0^{\circ} \mathrm{C}\right)$, then transferred to room temperature $\left(22^{\circ} \mathrm{C}\right)$ has not been previously reported to our knowledge. The delay in volatile synthesis for fruit stored in $\mathrm{RA}$ reached $0 \mathrm{~d}$ poststorage after about 5 months ( $150 \mathrm{~d}$ ) storage, which roughly agrees with the delay in softening brought about by a single 1-MCP treatment of 'Redchief Delicious' fruit stored at $0{ }^{\circ} \mathrm{C}$ (Mir et al., 2001). Important among the findings in the 

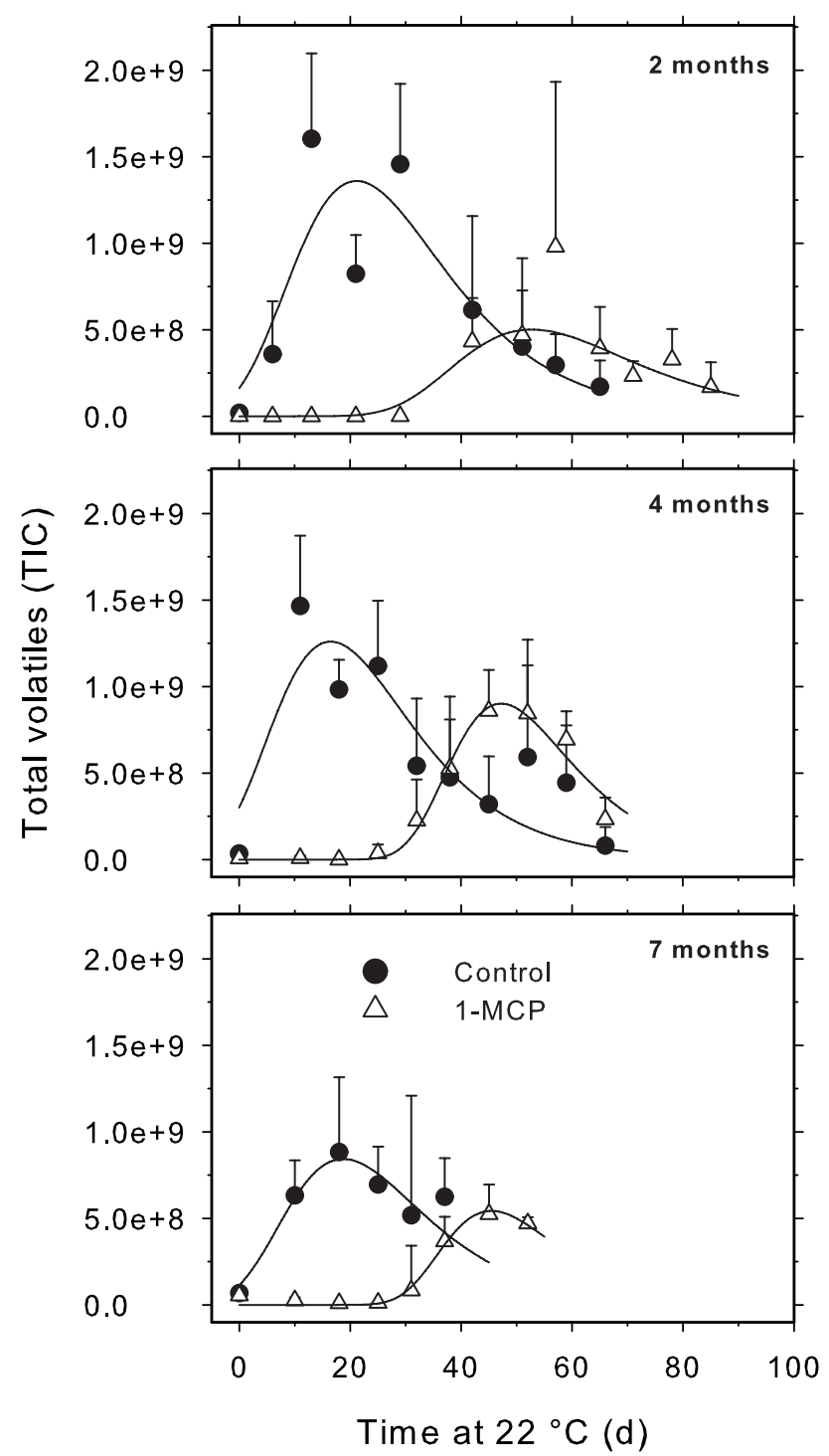

Fig. 8. Total ion count (TIC) for volatiles produced by 'Jonagold' and 'Redchief Delicious' apple fruit treated with $1 \mathrm{~mL} \cdot \mathrm{L}^{-1} 1-\mathrm{MCP}$ (open triangles) or left nontreated as controls (solid circles) following controlled atmosphere storage (1.5 $\mathrm{kPa} \mathrm{O}_{2}, 3 \mathrm{kPa} \mathrm{CO}, 0^{\circ} \mathrm{C}$ ) for 2,4 , or 7 months while being held at $22^{\circ} \mathrm{C}$.

current study is that the impact of 1-MCP on volatile synthesis does not appear to diminish at low temperature for at least the first $30 \mathrm{~d}$ in RA storage and for the first $60 \mathrm{~d}$ in CA. Afterwards, the decline in the delay in volatile synthesis suggests a decline in the 'resistance' to ripening initially imposed by 1 -MCP. It is possible that 1-MCP may occupy all available ethylene receptors at the preclimacteric stage in apple fruit, initially suppressing expression of new receptors. However, as 1-MCP dissociates and/or new receptors form, the extent of metabolic changes required to bring the fruit to an ethylene responsive state apparently declines, thus reducing the time needed for the recovery of volatile synthesis.

The residual effects of 1-MCP on the initiation of volatile recovery may be a problem if fruit are marketed soon after treatment, especially for cultivars like 'Gala' for which aroma constitutes a significant quality component (White, 1991). It appears likely that given the current apple distribution system in the United States, most fruit emerging from RA or CA storage would be through the retail segment and in the consumer's hands well before volatile
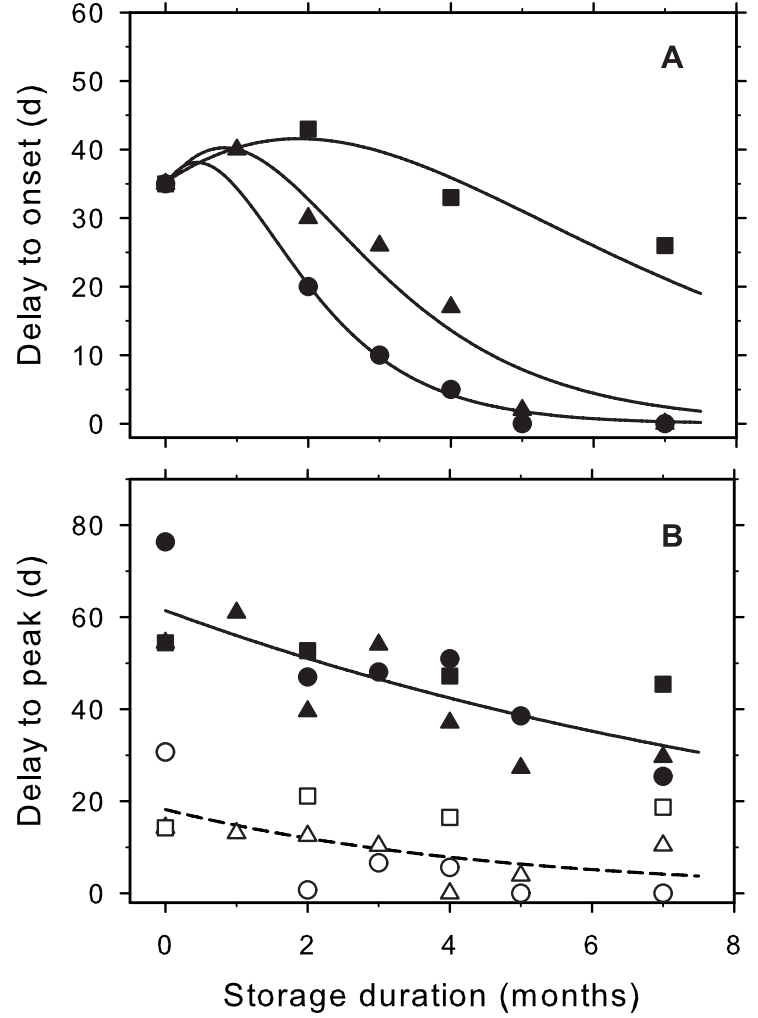

Fig. 9. Number of days during post-storage holding at $22{ }^{\circ} \mathrm{C}$ required for the onset (A) and peak (B) in volatile biosynthesis by 'Jonagold' apple following storage in refrigerated air (circles) and controlled atmosphere $\left(1.5 \mathrm{kPa} \mathrm{O}_{2}, 3 \mathrm{kPa}\right.$ $\mathrm{CO}_{2}$ ) (squares) and by 'Redchief Delicious' apple fruit stored in refrigerated air (triangles). Fruit were treated with $1 \mathrm{~mL} \cdot \mathrm{L}^{-1} 1-\mathrm{MCP}$ (solid symbols) or were left non-treated as controls (open symbols). The time required for onset of volatile biosynthesis for control fruit was $0 \mathrm{~d}$ for both cultivars following all storage durations with the exception of 0 months storage for 'Redchief Delicious', when $5 \mathrm{~d}$ passed before volatile production commenced.

recovery would commence for fruit held in RA 0 to 3 months and in CA for 7 months or less. However, it must be acknowledged that a significant quantity of aroma-related volatiles in apple is produced via cell disruption occurring during the process of mastication (Paillard, 1986). The fact that autonomous and disruption-dependent volatile synthesis are responsible for aroma perception may explain the relatively small impact of 1-MCP on aroma perception for 1-MCP-treated 'Anna' fruit (Lurie et al., 2002), which were cut prior to sensory assessment. The lack of a more significant impact in this study may also reflect a less complete inhibition of volatile formation by 1-MCP treatment than in the current study. The impact of 1-MCP on the capacity of apple fruit to produce volatiles requiring tissue disruption has received limited attention. Defilippi et al. $(2004,2005)$ found that 1-MCP treatment of 'Greensleeves' apple fruit did not markedly reduce saturated and unsaturated 6-carbon aldehydes resulting from lipoxygenase activity in disrupted cells.

The reduced maximum rate of volatile biosynthesis following 1-MCP and CA treatments is not easily explained based on ethylene biology alone given that, in the current study, ethylene biosynthesis recovered following $\mathrm{CA}$ and 1-MCP treatments (data not shown). The data suggest that permanent changes in gene expression and metabolism are induced by these treatments when applied prior to ripening. The shift in volatile forming capacity might reflect global shifts in metabolic behavior or might result from more specific effects on the substrates and enzymes 
essential for formation of esters (Patterson et al., 1974). The importance of reduced maximal volatile formation in terms of sensory quality may be minimal. The peak in production does not necessarily correspond with the best eating quality and may, in fact, be more indicative of the onset of senescence. Saftner et al. (2005) found that softening of fruit of several apple cultivars held in RA storage preceded or was coincident with the peak in volatile synthesis. As the duration of storage increased, the number of days between the onset of volatile formation and the peak in volatile biosynthesis did not appear to increase or decrease for 1-MCP-treated fruit. The implication is that the processes associated with volatile recovery were relatively similar throughout storage and independent of the processes governing the delay to onset of volatile recovery.

The data here document that 1-MCP, through its action on ethylene perception, delays the onset of volatile production in a temperature-dependent manner and permanently suppresses the maximal amount of volatile synthesis in a manner similar to CA storage. For 'Jonagold' and 'Redchief Delicious' fruit, the delay in the recovery of volatile formation following removal from storage conditions exceeded 3 weeks for the first 2 or 3 months in RA and for the first 7 months in CA. The implication is that some components of fruit aroma character may be compromised when fruit are consumed during these marketing periods. A detailed study of the ontogeny of fruit quality perception or 1-MCP-treated fruit may be needed to assess whether the documented reductions in volatile production shown here result in important changes in sensory quality and/or product value.

\section{Literature Cited}

Abdi, N., W.B. McGlasson, P. Holford, M. Williams, and Y. Mizrahi. 1998. Responses of climacteric and suppressed-climacteric plums to treatment with propylene and 1-methylcyclopropene. Postharvest Biol. Technol. 14:29-39.

Bartley, I.M., P.G. Stoker, A.D.E. Martin, S.G.S. Hatfield, and M. Knee. 1985. Synthesis of aroma compounds by apples supplied with alcohols and methyl esters of fatty acids. J. Sci. Food Agr. 36:567-574.

Boylston, T.D., E.M. Kupferman, J.D. Foss, and C. Buering. 1994. Sensory quality of Gala apples as influenced by controlled and regular atmosphere storage. J. Food Quality 17:477-494.

Brackmann, A., J. Streif, and F. Bangerth. 1993. Relationship between a reduced aroma production and lipid metabolism of apples and after long term controlled-atmosphere storage. J. Amer. Soc. Hort. Sci. 118:243-247.

Bradford, M.M. 1976. Arapid and sensitive method for the quantification of microgram quantities of protein utilizing the principle of protein-dye binding. Anal. Biochem. 72:248-254.

Burg, S.A, and E.A. Burg. 1962. Role of ethylene in fruit ripening. Plant Physiol. 37:179-189.

Defilippi, B.G., A.M. Dandekar, and A.A. Kader. 2004. Impact of suppression of ethylene action or biosynthesis on flavor metabolites in apple (Malus domestica Borkh.) fruits. J Agr. Food Chem. 52:5694-5701.

Defilippi, B.,A.A. Kader, and A.M. Dandekar. 2005.Apple aroma:Alcohol acyltransferase, a rate limiting step for ester biosynthesis, is regulated by ethylene. Plant Sci. 168:1199-1210.

Dixon, J. and E.W. Hewett. 2000. Factors affecting apple aroma/flavour volatile concentration: A review. N.Z. J. Crop Hort. Sci. 28:155-173.

Fan X., J.P. Mattheis, and D. Buchanan. 1998. Continuous requirement of ethylene for apple fruit volatile synthesis. J. Agr. Food Chem. 46:1959-1963.

Fan, X., J. P. Mattheis, and S. Blankenship. 1999. 1-Methylcyclopropene inhibits apple ripening. J. Amer. Soc. Hort. Sci. 124: 690-695.

Fan, X. and J.P. Mattheis. 1999. Impact of 1-methylcyclopropene and methyl jasmonate on apple volatile production. J. Agr. Food Chem. 47:2847-2853.
Fellman, J.K., T.W. Miller, D.S. Mattinson, and J.P. Mattheis. 2000. Factors that influence biosynthesis of volatile flavor compounds in apple fruit. HortScience 35:1026-1033.

Golding, J.B., D. Shearer, W.B. McGlasson, and S.G. Wyllie. 1999. Relationships between respiration, ethylene, and aroma production in ripening banana. J. Agr. Food Chem. 47:1646-1651.

Golding, J.B., D. Shearer, S.G. Wyllie, and W.B. McGlasson. 1998. Application of 1-MCP and propylene to identify ethylene-dependent ripening processes in mature banana fruit. Postharvest Biol. Technol. 14:87-98.

Gorny, J. and A. Kader. 1996. Controlled-atmosphere suppression of ACC synthase and ACC oxidase in 'Golden Delicious' apples during long-term cold storage. J. Amer. Soc. Hort. Sci. 121:751-755.

Hulme,A.C. 1954. Studies on the maturity of apples. Respiration progress curves for Cox's Orange Pippin apples for a number of consecutive seasons. J. Hort. Sci. 29:142-149.

Hulme, A.C., J.D. Jones, and S.C. Wooltorton. 1963. The respiration climacteric in apple fruits. Proc. Royal Soc., B, 158:514-535.

Jayanty, S., J. Song, N.M. Rubinstein, A. Chong, and R.M. Beaudry. 2002. Temporal relationship between ester biosynthesis and ripening events in banana. J. Amer. Soc. Hort. Sci. 127:998-1005.

Jayanty, S., M. Cañoles, and R.M. Beaudry. 2004. Concentration-dependence of 'Redchief Delicious' apple fruit softening and chlorophyll fluorescence to repeated doses of 1-methylcyclopropene. J. Amer. Soc. Hort. Sci. 129:760-765.

Jones, J.D., A.C. Hulme, and L.S.C. Wooltorton. 1965. The respiration climacteric in apple fruits: Biochemical changes occurring during the development of the climacteric in fruit detached from the tree. New Phytol. 64:158-167.

Kondo, S., S. Setha, D. Rudell, D.A. Buchanan, and J.P. Mattheis. 2005. Aroma volatile biosynthesis in apples affected by 1-MCP and methyl jasmonate. Postharvest Biol. Technol. 36:61-68.

Laemmli,U.K. 1970. Cleavage of structural proteins during the assembly of the head of bacteriophage T4. Nature 227:680-685.

Looney, N.E. 1969. Control of apple ripening by succinic acid 2,2dimethyl hydrazide, 2-chloroethyltrimethylammonium chloride, and ethylene. Plant Physiol. 44:1127-1131.

López-Gómez, R. and M.A. Gómez-Lim. 1992. A method for extracting intact RNA from fruits rich in polysaccharides using ripe mango mesocarp. HortScience 5:440-442.

Lurie, S., C. Pre-Aymard, U. Ravid, O. Larkov, and E. Fallik. 2002. Effect of 1-methylcyclopropene on volatile emission and aroma in cv. Anna apples. J. Agr. Food Chem. 50:4251-4256.

Mattheis, J.P., D.A. Buchanan, and J.K. Fellman. 1995. Volatile compound production by 'Bisbee Delicious' apples after sequential atmosphere storage. J. Agr. Food Chem. 43:194-199.

Mattheis, J.P, X. Fan, and L.C. Argenta. 2005. Interactive responses of Gala apple fruit volatile production to controlled atmosphere storage and chemical inhibition of ethylene action. J. Agr. Food Chem. 53:4510-4516.

Mir, N.A, E. Curell, N. Khan, M. Whitaker, and R.M. Beaudry. 2001. Harvest maturity, storage temperature, and 1-MCP application frequency alter firmness retention and chlorophyll fluorescence of 'Redchief Delicious' apple fruit. J. Amer. Soc. Hort. Sci. 125:618-624.

Mir, N., M. Cañoles, R. Beaudry, E. Baldwin, and C. Mehla. 2004. Inhibition of tomato ripening by 1-methylcyclopropene. J. Amer. Soc. Hort. Sci. 129:112-120.

Nakatsuka, A., S. Shiomi, Y. Kubo, and A. Inaba. 1997. Expression and internal feedback regulation of ACC synthase and ACC oxidase genes in ripening tomato fruit. Plant Cell Physiol. 38:1103-1110.

Paillard, N.M.M. 1986. Evolution of the capacity of aldehydes production by crushed apple tissues, during an extended storage of fruits, p. 369-378. In: G. Charalambous (ed.). The shelf-life of foods and beverages. Elsevier Science, Amsterdam, The Netherlands.

Patterson, B.D., S.G.S. Hatfield, and M. Knee. 1974. Residual effects of controlled atmosphere storage on the production of volatile compounds by two cultivars of apples. J. Food Sci. Agr. 25:843-849.

Plotto, A., M.R. McDaniel, and J.P. Mattheis. 1999. Characterization of 
'Gala' apple aroma and flavor: Differences between controlled atmosphere and air storage. J. Amer. Soc. Hort. Sci. 124:416-423.

Plotto, A., M.R. McDaniel, and J.P. Mattheis. 2000. Characterization of 'Gala' apple aroma during storage using Osme analysis, a gas chromatogtaphy-olfactometry technique. J. Amer. Soc. Hort. Sci. 125:714-722.

Saftner, R.A., J.A. Abbott, A.A. Bhagwat, and B.T. Vinyard. 2005. Quality measurement of intact and fresh-cut slices of Fuji, Granny Smith, Pink Lady, and Goldrush apples. J. Food Sci. 70:317-324.

Saftner, R.A., J.A. Abbott, and W.S. Conway. 2003. Effects of 1-methylcyclopropene and heat treatments on ripening and postharvest decay in 'Golden Delicious' apples. J. Amer. Soc. Hort. Sci. 128:120-127.

Sambrook, J., E.F. Fritsch, and T. Maniatis. 1989. Molecular cloning: A laboratory manual, 2nd ed. Cold Spring Harbor Laboratory Press, Plainview, N.Y.

Sisler, E.C. and M. Serek. 1997. Inhibitors of ethylene responses in plants at the receptor level: Recent developments. Physiol. Plant. 100:577-582.
Song, J. and F. Bangerth. 1996. The effect of harvest date on aroma compound production from 'Golden Delicious' apple fruit and relationship to respiration and ethylene production. Postharvest Biol. Technol. 8:259-269.

Song, J., B. Gardener, J. Holland, and R. Beaudry. 1997. Rapid analysis of volatile flavor compounds in horticultural produce using SPME and GC/time-of-flight mass spectrometry. J. Agr. Food Chem. 45:1801-1807.

Souleyre, E.J.F., D.R. Greenwood, E.N. Friel, S. Karunairetnam, and R. Newcomb. 2005. An alcohol acyl transferase from apple (cv. Royal Gala), MpAAT1, produces esters involved in apple fruit flavor. FEBS J. 272:3132-3144.

Tian, M.S., J.H. Brown, A.D. Bauchot, Y.P. Gong, and N. Lallu. 1997. Recovery of ethylene biosynthesis in diazocyclopentadiene (DACP)treated tomato fruit. Plant Growth Regulat. 22:73-78.

White, A.G. 1991. The 'Gala' apple. Fruit Var. J. 45:2-3. Williams, A.A. and S.P. Langron. 1983. Influence of different controlled atmospheres and poststorage temperatures on the acceptability of Cox's Orange Pippin and Suntan apples. J. Sci. Food Agr. 34:1375-1382. 